REVISTA de

PEDAGOGIE

http://revped.ise.ro

Print ISSN 0034-8678; Online ISSN: 2559 - 639X

\title{
A DISCOURSE ANALYSIS OF CLASS INTERACTIONS
}

O analiză de discurs a interacțiunilor din clasa de elevi

\section{Elena UNGUREANU}

\author{
Journal of Pedagogy, 2020 (2), 49 - 69 \\ https://doi.org/10.26755/RevPed/2020.2/49
}

The online version of this article can be found at: http://revped.ise.ro/en/2020/

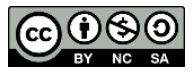

This work is licensed under the Creative Commons Attribution-NonCommercial-ShareAlike 4.0 International License.

To view a copy of this license, visit http://creativecommons.org/licenses/by-nc-sa/4.0/ or send a letter to Creative Commons, PO Box 1866, Mountain View, CA 94042, USA

Published by:

Centrul Național de Politici și Evaluare în EduCație

UNITATEA DE CERCETARE ÎN EDUCAȚIE

http://www.ise.ro/

https://rocnee.eu/

Further information about Revista de Pedagogie - Journal of Pedagogy can be found at:

Editorial Policy: http://revped.ise.ro/editorial-policy/

Author Guidelines: http://revped.ise.ro/en/author-guidelines/ 


\title{
O ANALIZĂ DE DISCURS A INTERAC IUNILOR DIN CLASA DE ELEVI
}

\section{Elena Ungureanu*}

\author{
Universitatea din Bucureşti, \\ Facultatea de Psihologie şi Ştiin ele Educa iei, \\ Bucureşti, România \\ elena_ungureanu@drd.unibuc.ro
}

\section{Rezumat}

În acest articol analizez contextul discursiv din două clase de elevi aducând în discu ie conceptele de cunoaştere educa ională şi organizarea activită ilor de predareînvă are. Deşi există multe cercetări care oferă în elegeri nuan ate asupra modului în care profesorii şi elevii sunt implica i în construc ia socială a discursurilor de la clasă despre cunoaştere, în literatura românească chestiunea interac iunilor din clasa de elevi a fost abordată din perspectiva percep iilor profesorilor şi elevilor, în timp ce cunoaşterea şcolară a fost abordată tangen ial. De aceea, prezint un studiu calitativ, fundamentat pe o analiza de discurs de tip critic, prin care eviden iez cum diferite versiuni de cunoaştere sunt social construite în spa iul discursiv al clasei, cu scopul de a eviden ia modalită i prin care clasa de elevi şi şcoala pot deveni spa ii în care interac iunile nu mai gravitează în jurul cunoaşterii definită doar prin raportare la con inuturile disciplinare. Observări bilunare şi înregistrări audio-video au fost realizate în anul şcolar 2017-2018 în timpul activită ilor de limbă şi comunicare, la două clase din ciclul primar, din două şcoli diferite. Rezultatele arată că interac iunile din clasă şi structurile de participare diferă în func ie de scopul activită ilor, iar participarea elevilor nu are la bază doar reguli de comunicare general acceptate, ci variază în func ie de scopul implicit sau explicit al activită ilor.

Cuvinte-cheie: analiză de discurs, cunoaştere şcolară, curriculum, interac iuni, participarea elevilor.

* Doctorand, Universitatea din Bucureşti, Facultatea de Psihologie şi Ştiin ele Educa iei, Departamentul Ştiin ele Educa iei, Bucureşti, România. 


\section{Abstract}

In this article I analyse the discursive context of two classes of students bringing into discussion the concepts of educational knowledge and the organization of teaching-learning activities. Although there is much research that provides nuanced insights into how teachers and students are involved in the social construction of classroom discourses about knowledge, in Romanian literature the issue of classroom interactions has been approached from the perspective of teachers ' and students' perceptions, while school knowledge has been studied only incidentally Therefore, I present a qualitative study, based on a critical discourse analysis that highlights how different versions of knowledge are socially constructed in the discursive space of the classroom, in order to point out ways in which the classroom and school can become spaces in which interactions no longer revolve around knowledge defined only by reference to disciplinary content. Bimonthly observations and audio-video recordings were made in the 2017-2018 school year during language and communication activities, in two classes, from two different schools. The results show that classroom interactions and participation structures differ depending on the purpose of the activities, and student participation is not only based on generally accepted communication rules, but varies depending on the implicit or explicit purpose of the activities.

Keywords: classroom discourse analysis, curriculum, interactions, school knowledge, students participation.

\section{Introducere}

Studiile discursive din clasa de elevi au eviden iat încă din 1960 modul în care interac iunile şi con inutul vorbirii oferă în elegeri nuan ate asupra ordinii sociale din acest spa iu. Chestiunea interac iunilor a fost analizată în strânsă legătură cu discursurile de la clasă şi tipurile de cunoaştere educa ională (Moje, 2008). Pentru ca discursul de la clasă să devină un spa iu interac ional participativ, literatura de specialitate ne spune că ar trebui să fie caracterizat de tipare de interac iune care să permită elevilor să participe prin limbaje proprii (Rymes, 2016).

Analiza interac iunilor utilizate în cadrul activită ilor de predare - învă are poate ilustra procesul de construc ie socială a cunoaşterii educa ionale, ca parte a discursului din clasa de elevi. Această analiză poate fi realizată 
definind tiparele de interac iune şi activită ile de la clasă, ca resurse de cadrare a discursurilor, în elese ca moduri de a vorbi şi cunoaşte (Edwards \& Mercer, 1987; Moje, 2008).

Cercetările anterioare au urmărit, printre altele, şi în elegerea şi descrierea modului în care profesorii şi elevii sunt implica i în construc ia socială a discursurilor din clasă (Cazden, 2001; Garton, 2012; Heller, 2017; Houen et al., 2018; Philips, 1993), acordând aten ie specială limbajului, ca proces şi instrument, prin care via a socială a clasei este creată, negociată. Tiparele de interac iune şi structurile de participare au fost studiate pentru a în elege modul în care este creată o ecologie epistemică colectivă sau una care favorizează cunoaşterea individuală (Heller, 2017). Aceste studii au arătat că gestionarea discursului la clasă este un factor important, dacă se doreşte o predare orientată conversa ional, prin care să fie create spa ii interac ionale incluzive, care să ducă la rezultatele şcolare dorite.

În literatura românească, problematica interac iunilor din clasa de elevi a fost abordată (Bercu, Nasta \& Teşileanu, 2012; Iosifescu, 2012; Mihăilescu, 2016; Vlăsceanu, 2002) din perspectiva percep iilor privind desfăşurarea acestora la clasă. În privin a cunoaşterii şcolare, abordarea este tangen ială, în studii precum ,Şcoala la răscruce”, dar şi în analizele ce înso esc documentele de politici curriculare (ISE, 2019). Ceea ce ar întregi tabloul oferit de aceste documente şi studii este o analiză a modului în care interac iunile se desfăşoară la clasă, în timpul procesului de predare-învă are. În acest articol, mi-am propus să analizez contextul discursiv din două clase de elevi, având în vedere concepte, precum cunoaşterea educa ională şi organizarea activită ilor de predare-învă are. Mai specific, prezint un studiu fundamentat pe o analiza de discurs de tip critic, cu elemente de microetnografie (Bloome et al., 2005; Rynes, 2016), în care, analizând organizarea activită ilor de la clasă, eviden iez cum diferite versiuni de cunoaştere sunt social construite în spa iul discursiv al clasei.

Scopul analizei este sublinierea modalită ilor prin care clasa de elevi, şcoala pot deveni spa ii în care vocile elevilor sunt recunoscute ca fiind mai degrabă productive, în procesul de construc ie a cunoaşterii din clasă, iar interac iunile nu mai gravitează în jurul cunoaşterii de tip şcolar definită doar prin raportare la con inuturile disciplinare. 


\section{Cadrul teoretic}

Conceptele pe care analiza prezentată în acest articol se sprijină se referă la cunoaştere, cunoaştere educa ională şi şcolară, discurs, resurse de cadrare şi structuri de participare.

\subsection{Cunoaşterea în clasa de elevi}

În epistemologie, cunoaşterea este văzută ca fiind opusul opiniilor. În psihologia cognitivă, conceptul de cunoaştere a fost extins pentru a include toate convingerile unei persoane pe baza cărora ac ionează (Bereiter, 2001). Cunoaşterea este unul dintre conceptele de bază ale procesului educa ional (Bruner, 1996; Cunningham \& Fitzgerald, 1996), deşi nu este unica finalitate. Goldman (1999) afirmă despre cunoaşterea de tip declarativ că reprezintă scopul cel mai caracteristic: ceea ce numim con inuturi şcolare sunt prezentate în clasă sub forma a ceea ce poate fi, generic, numit ,cunoaştere” (chiar şi în condi iile unei educa ii orientate către formarea de competen e). Edward şi Mercer (1987) men ionează despre cunoaşterea şcolară că nu are grani e clare, fuzionând uneori cu, în elegeri sociale şi experien e diverse pe care copilul le achizi ionează de-a lungul anilor de şcolarizare" (p. 2). În cadrul discursului de la clasă, spun autorii, cunoaşterea şcolară este continuu marcată, delimitată şi întărită. Putem astfel vorbi despre ceea ce al i autori au numit culturi epistemologice sau ecologii epistemice (Heller, 2017).

Într-o altă ordine de idei, Cazden (2001) men iona că una dintre întrebările la care a răspuns în lucrarea „Classroom Discourse” priveşte modul în care tiparele de limbaj utilizate influen ează ceea ce reprezintă cunoaşterea şi învă area în clasa de elevi. Autoarea remarca faptul că profesorii sunt confrunta i la clasă cu dilema reconcilierii a două scopuri: respectarea gândirii elevilor şi transmiterea/facilitarea învă ării ,cunoaşterii conven ionale şi a procedurilor" (Cazden, 2001, p.56). Ceea ce e numit cunoaştere conven ională se referă la ceea ce e prevăzut prin curriculumul şcolar. Cealaltă formă de cunoaştere - cea exprimată de elevi - se poate afla într-un raport de opozi ie sau complementaritate cu prima. Ceea ce mi se pare remarcabil la analiza realizată de Cazden are legătură cu existen a şi afirmarea dilemei în spa iul şcolar, implicând ideea ca prezen a celor două forme de cunoaştere să fie acceptată, supusă analizei. 
Există sisteme de educa ie în care conceptul de cunoaştere nu este chestionat, statutul său epistemologic nu necesită vreo justificare. Cunoaşterea şcolară este dată şi nu intră în competi ie cu alte forme, nu la nivel explicit. În acest caz, dilema diferitelor forme de cunoaştere nu există, pentru că ceea ce apare în spa iul discursiv al clasei este separat de cunoaşterea exterioară. Moore şi Young (2001) explică faptul că, într-o concep ie tradi ională asupra curriculumului, nu există o preocupare pentru cunoaştere şi statutul său epistemologic. Educa ia este orientată către formarea în spiritul valorilor, normelor şi cunoaşterii întemeiate prin autoritatea tradi iei.

În analiza prezentată în acest articol, conceptul de cunoaştere educa ională desemnează versiuni de cunoaştere care apar în spa iul şcolar, incluzând ceea ce profesorul transmite - cunoaşterea şcolară - dar şi ceea ce elevii exprimă sub forma cunoaşterii cotidiene şi personale, exprimată prin nara iunile şi interven iile lor spontane.

Cunoaşterea educa ională este analizată într-o perspectivă discursivă ce presupune analizarea limbajului şi interac iunilor utilizate în predare-învă are (Markee, 2015). În tradi iile antropologiei lingvistice, sociologiei, lingvisticii textului şi analizei critice de discurs (CDA), discursul este definit ca limbaj în context, adică modul în care limbajul este utilizat în diferite situa ii sociale, iar analiza de discurs se referă la studiul modului în care limbajul este influen at de contextul utilizării sale (Rymes, 2016). În studiul prezentat în acest articol discursul despre cunoaştere educa ională se referă la limbajul din contextul clasei, utilizat pentru a vorbi despre con inuturile şcolare, dar şi despre alte con inuturi, din afara şcolii.

\subsection{Resursele de cadrare din contextele discursive ale clasei}

În logica abordării discursive, cunoaşterea fiecărei persoane participante la o situa ie de comunicare este contextualizată prin conven ii de cadrare, astfel construindu-se şi discursul de la clasă. Un elev ar putea şti să spună o poveste într-o manieră diferită de cea agreată la şcoală. Când decide să participe la spa iul clasei cu povestea lui, afişarea ei este realizată în cadrul structurilor de participare de la clasă, a obiectivelor pe care profesorul le are pentru o anumită activitate. Astfel, cunoaşterea elevului privind forma poveştii şi 
con inutul acesteia contribuie, productiv sau disruptiv, la construc ia discursului din clasă (Rymes, 2016). Cu alte cuvinte, contribu ia elevului este văzută ca fiind potrivită, valoroasă (productivă) sau este considerată a fi o întrerupere, fiind ignorată sau invalidată (disruptivă).

Fundamentat pe abordarea discursivă propusă de Betsy Rymes (2016), acest studiu utilizează conceptul de context discursiv tridimensional: de tip social, interac ional şi individual. Cele trei trebuie în elese în rela ie cu conceptul de cadru (Goffman, 1974). În contextele discursive, putem regăsi cadre, numite în continuare resurse de cadrare, care modelează interac iunile şi limbajul, iar ele sunt specifice fie contextului social, fie celui interac ional, fie celui individual (acesta din urmă nu este abordat în articol). Contextul social se referă, în termenii lui Rymes, la acei factori sociali din afara ,interac iunii imediate" care influen ează modul în care este utilizat limbajul. Un astfel de cadru poate fi reprezentat de scopurile şi obiectivele şcolii şi sistemului educa ional (prin curriculum), precum şi ale activită ilor, la nivel micro. Prin urmare, activitatea de predare - învă are ar putea constitui un context care modelează utilizarea limbajului în clasă, fiind una dintre resursele de cadrare de la nivelul social. Contextul interac ional se referă la interac iunile imediate şi la secven ialitatea vorbirii. Acesta influen ează ceea ce putem spune sau nu (în activită ile de evaluare, interven iile libere ale elevilor sunt taxate, dar în activită ile de predare sau de tranzi ie, sunt acceptate şi apreciate). În lumina acestui concept, putem analiza, de exemplu, rândul la vorbire, cine şi când spune ceva, pentru a în elege cum e cadrat discursul. Bloome et al. (2005) arată că interpretarea interac iunilor la clasă, în privin a rândului la vorbire, este dificil de realizat, recomandând utilizarea conceptului de structuri de participare. Acestea sunt definite ca reguli mutual împărtăşite, care reglementează interven iile participan ilor la contextul discursiv. Philips, citată de Rymes, le defineşte ca fiind ,moduri de aranjare a interac iunii verbale cu elevii”' (Philips, 1972, p. 377, apud Rymes, 2016), eviden iind că în clasa de elevi, pe măsură ce se face trecerea de la o structură de participare la alta, se schimbă şi ceea ce spunem, şi cum spunem, şi cât spunem.

Studiul prezentat în acest articol nu are în vedere modul în care elevii înva ă cunoştin ele şcolare, ci modul în care diversele versiuni ale cunoaşterii educa ionale apar în evenimentele de comunicare de la clasă. De asemenea, am în vedere ilustrarea modului în care contextul social şi interac ional al 
discursului de la clasă contribuie la afişarea, gestionarea şi producerea cunoaşterii. Este important să abordăm modul în care cunoaşterea educa ională este transpusă la clasă, deoarece discursul - limbajul în context - este, în accep iune social construc ionistă, nu doar constituit, dar şi constitutiv (Cazden, 2001). În acest sens, am formulat următoarele întrebări de cercetare: cum sunt organizate activită ile de predare-învă are din punct de vedere interac ional?; func ionează activită ile de predare-învă are ca elemente care modelează discursurile din clasa de elevi?

\section{Metodologie}

\subsection{Colectarea datelor}

Datele analizate provin din observa ii bilunare şi înregistrări audio-video, care au fost realizate în timpul orelor comunicare în limba română, în timpului anului şcolar 2017/2018, şi însumează aproximativ douăzeci şi cinci de ore de înregistrări video şi audio pe parcursul a 36 de ore de clasă. Participan ii sunt elevi de la clasa pregătitoare, din două clase. Datele au fost culese în două şcoli generale, alese prin eşantionare de convenien ă. O şcoală se află în Bucureşti, cealaltă, într-o zonă rurală, urbanizată, din jude ul Ilfov. Consim ământul părin ilor a fost ob inut în scris. Datele audio-video ob inute sunt utilizate doar în scopul cercetării autoarei şi nu vor fi făcute publice în niciun context. Toate detaliile de identificare a şcolilor şi participan ilor au fost anonimizate.

\subsection{Analiza datelor}

Studiul de fa ă utilizează o abordare discursivă a interac iunilor cu o serie de elemente analitice împrumutate din analiza de discurs de tip microetnografic (Bloome et al., 2005) şi analiză de discurs de tip critic (Rymes, 2016). Am ales analiza de discurs pentru că această metodă îmi permite să dau seama de diversitatea situa iilor de comunicare din clasa de elevi şi de modul în care tiparele de interac iune func ionează pentru a structura această diversitate. 
Având în vedere că demersul de cercetare constă într-o analiză calitativă de tip inductiv, am focalizat interesul asupra în elegerii evenimentelor din clasa de elevi şi a aspectelor interac ionale/discursive care decurg de aici, în context instruc ional, rezultatele nefiind generalizabile. Utilitatea studiului este definită în termenii îmbogă irii semnifica iilor şi interpretărilor date contextelor de tip educa ional.

Pentru structurarea analizei am avut în vedere aspecte, precum: organizarea activită ilor de predare-învă are la clasă din punct de vedere al modului de interac iune; func ionarea activită ilor de predare-învă are şi identificarea caracteristicilor lor interac ionale, ca elemente de modelare a discursurilor din clasa de elevi. Am abordat aceste aspecte aplicând mai multe proceduri analitice, într-o manieră iterativă.

Studiul s-a desfăşurat în două etape. În prima etapă, am realizat o analiză de tip tematic prin codarea materialelor ( 25 de ore) şi tematizarea codurilor ob inute (Saldaña, 2009). Pentru codarea materialelor audio, am utilizat o tehnică de tip deductiv - inductiv şi am utilizat programul Dedoose. În urma primei faze a cercetării, am ob inut o nouă schemă de codare, ce a cuprins următoarele categorii: metode de instruire, tehnici de sanc ionare a participării, modalită i de atribuire a sarcinilor şi materialelor şi tipuri de interac iuni. Această schemă a fost utilizată pentru etapa a doua a cercetării, fiind aplicată pe 12 lec ii, desfăşurate în primul semestru al anului şcolar 2017-2018. Pentru codarea şi analiza calitativă din etapa a doua am utilizat programul MAXQDA. În această etapă a cercetării, am avut un nivel de granularitate mai mare, optând pentru activitate, ca unitate de analiză, în eleasă ca tip specific de interac iune dintre elevi şi profesor, având grani e verbale explicite, marcate în general de cadrul didactic prin indicarea finalizării activită ii, anumite interjec ii sau îndemnuri. Procesul a fost unul de tip iterativ, procedura de codare reluându-se de aproximativ trei ori, până când, am constatat că datele sunt descrise de codurile elaborate într-o manieră coerentă şi fidelă. De exemplu, m-am asigurat că interac iuni asemănătoare nu au fost codate diferit. Analiza este de tip descriptiv - interpretativ. Ulterior, am transcris fragmente din interac iunile de la clasă, în func ie de activită ile care au prezentat interes analitic. Transcrierea a fost realizată cuvânt cu cuvânt şi am utilizat sistemul Jefferson. 


\section{Rezultate}

3.1. Tipurile de activită i dezvoltate la orele de limbă şi comunicare

Procedurile analitice mi-au permis codarea celor 12 lec ii înregistrate şi definirea a 107 activită i, care au reprezentat unitatea de analiză. Utilizând schema de codare men ionată anterior, am realizat o caracterizare a tipurilor principale de activită i dezvoltate la clasă: activită i în care sunt realizate exerci ii de tip oral (24); activită i în care sunt realizate exerci ii la tablă (8); activită i în care sunt realizate exerci ii individuale pe caiet (19); activită i fizice (1); activită i cu caracter ludic-jocul didactic (3); activită i de produc ie orală colectivă (cântece, poezii) (4); activită i conversa ionale (42); activită i de ascultare/receptare a lecturii realizate de profesor (6). Se lucrează, în general, frontal sau individual. Există două activită i în care se utilizează tehnica lucrului în pereche. De asemenea, în nicio activitate materialele de învă are nu sunt diferen iate, nici sarcinile sau tipurile de activită i.

Analiza individuală a activită ilor, din punctul de vedere al metodelor utilizate, al tipurilor de interac iuni şi al tiparelor de participare, pe de-o parte, şi din punctul de vedere al con inutului întrebărilor, al tipurilor de răspunsuri ale elevilor, pe de altă parte, mi-au permis să identific o tipologie de activită i în func ie de scopul acestora. Am identificat următoarele scopuri: de predare, de exersare şi consolidare, de verificare şi de tranzi ie, pe care le voi descrie în continuare.

Categoria activită ilor de predare cuprinde activită i orale, fie sub forma unor exerci ii, fie sub forma conversa iei. Din totalul de 107 activită i, 15 sunt de predare. În cadrul acestora, elevii sunt numi i de profesor sau ridică mâna, dar sunt acceptate şi interven iile libere. Aten ionările profesorului sunt prezente, dar nu vizează restric ionarea rândului la vorbire şi au legătură cu aten ia elevilor sau păstrarea liniştii. Elevii au ocazia să completeze ceea ce spune profesorul, vorbesc despre cum se simt sau despre experien ele lor personale, subiecte care sunt în acord cu tema lec iei predate.

Fragmentul nr. 1 face parte dintr-o activitate de predare, conversa ională. Învă ătoarea (Î) a citit o poveste, după care a început o conversa ie cu elevii (E). Discu ia nu este orientată către verificarea în elegerii sau a memorării 
anumitor detalii şi putem observa o parte din caracteristicile activită ilor de predare enun ate anterior: elevii răspund numi i (rând 4), dar fac şi interven ii libere (rând $6,8,9,13$ ), ceea ce permite replica din rândul 13, a elevei, corectată ult0erior de cadrul didactic: ,noi nu spunem aşa la şcoală”.

Tabelul nr. 1. Fragment conversa ie $n r .1$

\begin{tabular}{|l|l|}
\hline Interac iuni verbale & $\begin{array}{l}\text { Structură } \\
\text { participare }\end{array}$ \\
\hline 1.I: El ce a făcut cu bietul iepuraş? Care era mai neştiutor. & $\hat{\text { I }}$ \\
\hline 2.I: Dacă l-a pus să plătească ce-a mâncat el? & $\hat{\mathrm{I}}$ \\
\hline $\begin{array}{l}\text { 3.I: Faptul că ogarul a mâncat şi a spus "ah, stai că mi-am uitat banii acasă, } \\
\text { plăteşte tu" asta ce înseamnă că încerca să facă cu iepuraşul? Gabriela. }\end{array}$ & $\hat{\mathrm{I}}$ \\
\hline 4.G: Ah...ah.. & E \\
\hline 5.I: Faptul că iepuraşul era mai neştiutor, mai neumblat prin lume & $\hat{\mathrm{I}}$ \\
\hline 6.E: Că....ahhhh & E \\
\hline 7.I: A încercat să-1? & $\hat{\mathrm{I}}$ \\
\hline 8.E: A încercat să-1... să-1... & E \\
\hline 9.G: Ahhh...a încercat să-1 păcălească? & E \\
\hline 10.I: Zi, Gabriela, tare! & $\hat{\mathrm{I}}$ \\
\hline 11.G: A încercat să-l păcălească... & E \\
\hline 12.I: A încercat să-l păcălească, să-l jefuiască cu alte cuvinte, asta pentru că... & $\hat{\mathrm{I}}$ \\
\hline 13.E: Să facă mişto de el! & E \\
\hline $\begin{array}{l}\text { 14.I: Daaaa... cum ar spune, aşa, popular, oamenii pe stradă. Dar noi nu } \\
\text { spunem aşa la şcoală. Da, a încercat să îl păcălească. }\end{array}$ & $\hat{\mathrm{I}}$ \\
\hline
\end{tabular}

Activită ile de tranzi ie fac trecerea de la o activitate la alta şi constituie o categorie de activită i în care elevii realizează o activitate de relaxare sau participă la organizare, la discu ii despre ceea ce urmează, fiind în număr de 26. Elevii pot face interven ii libere, fără a ridica mâna, cadrul didactic se adresează colectiv, dar şi individual. Aten ionările realizate de învă ătoare nu vizează rândul la vorbire, ci con inutul vorbirii sau păstrarea liniştii.

În tabelul nr. 2, în timp ce învă ătoarea împarte fişele pentru următoarea activitate, un elev ini iază o discu ie despre ora de sport. Interven ia e liberă, însă e invalidată de învă ătoare, nu pentru că ar încălca o regulă de 
comunicare, ci din cauza con inutului. Interesul lor - sportul - nu face obiectul interesului profesorului, în acel moment. $\mathrm{Cu}$ toate acestea, în rândul 4, observăm clarificările oferite, astfel încât elevii să se poate orienta temporal.

Tabelul nr. 2. Fragment de conversa ie $n r .2$

\begin{tabular}{|l|l|}
\hline Interac iuni verbale & $\begin{array}{l}\text { Structură } \\
\text { participare }\end{array}$ \\
\hline 1.E1: Doamna, e la trei? & E \\
\hline $\begin{array}{l}\text { 2.I: Ahhh... Alexandru, zău, dacă nu m-a i obosit cu ora asta de sport, de m-a i } \\
\text { ame it de azi diminea ă. }\end{array}$ & $\hat{\mathrm{I}}$ \\
\hline 3.E2: Da' nouă ne place sportul! & $\mathrm{E}$ \\
\hline $\begin{array}{l}\text { 4.I: Da' nu mă interesează, acuma, ne vedem întâi de treabă şi, după, vă duce i } \\
\text { şi la ora de sport. V-am spus că e ora a treia? Adică după ce mânca i masa de } \\
\text { diminea ă? }\end{array}$ & $\hat{\mathrm{I}}$ \\
\hline 5.E2: Da. & E \\
\hline 6.I: Bun. Eu cred ca am vorbit destul de clar. & $\hat{\mathrm{I}}$ \\
\hline
\end{tabular}

Pe de altă parte, fragmentul nr. 3 reprezintă un dialog între învă ătoare şi elevi, în cadrul unei activită i conversa ionale de tranzi ie, ce face trecerea către un exerci iu la tablă. Elevii răspund liber şi ini iază conversa ii. În acest exemplu, un elev o întrerupe pe învă ătoare pentru a-şi exprima dezamăgirea că nu înva ă litera „L”. Învă ătoarea le răspunde, ceea ce atrage şi întrebarea ,când le va aduce o literă nouă?'. Este o curiozitate căreia învă ătoarea, din nou, îi dă curs, validând deci întrebarea elevului. Interven iile elevilor nu sunt taxate.

Tabelul nr. 3. Fragment de conversa ie $n r .3$

\begin{tabular}{|c|c|}
\hline Interac iuni verbale & $\begin{array}{l}\text { Structură } \\
\text { participare }\end{array}$ \\
\hline 1.Î: Bun, gata! Hai ne apucăm şi noi de treabă? & $\hat{\hat{I}}$ \\
\hline 2.Ee: Daaa! & $\mathrm{E}$ \\
\hline 3.1̂: Aveam...Ahh... Vreau să continuăm astăzi aventurile elefăn elului... & $\hat{I}$ \\
\hline 4.E1: Eli! (exclamă o elevă) & $\mathrm{E}$ \\
\hline 5.Î: Gata! & $\hat{I}$ \\
\hline 6.E2: Eu credeam că îl învă ăm pe L (cu voce tristă)... & $\mathrm{E}$ \\
\hline $\begin{array}{l}\text { 7.Î: Ahh, nu încă! Am spus ca săptamâna aceasta vei primi fişa şi vei mai } \\
\text { primi o fişă... }\end{array}$ & $\hat{I}$ \\
\hline 8.E3: Când ne mai aduce i o literă? & $\mathrm{E}$ \\
\hline 9.1̂: O să învă ăm săptămâna viitoare o literă nouă. & $\hat{\mathrm{I}}$ \\
\hline 10.E4: Care? & $\mathrm{E}$ \\
\hline 11.Î: Pe N îl învă ăm. & $\hat{\mathrm{I}}$ \\
\hline 12.Ee: Nnnn! & $\mathrm{E}$ \\
\hline 13.Î: Ia, fi i aten i! & $\hat{\mathrm{I}}$ \\
\hline
\end{tabular}


În activită ile de exersare/consolidare, în număr de 32, creşte numărul situa iilor în care elevii răspund fie numi i, fie ridicând mâna şi scade numărul situa iilor în care elevii pot participa liber. Am observat că numărul situa iilor în care elevii participă prin ridicare de mână este mai mare decât numirile realizate de profesor, ceea ce poate arăta caracterul voluntar al participării la spa iul exersării. Creşte şi numărul de aten ionări, însă acestea privesc comportamentele elevilor care nu înlesnesc aten ia şi participarea. În plus, spre deosebire de activită ile de verificare, în cadrul celor de exersare, învă ătoarea oferă sprijin.

Fragmentul din tabelul nr. 4, face parte dintr-o activitate de exersare la tablă. Învă ătoarea numeşte un elev, care anterior îşi exprimase dorin a să iasă la tablă. Elevilor nu le sunt permise interven ii (rând 10), pentru că într-o astfel de activitate este încurajată aten ia pe rezolvarea individuală a sarcinii.

Tabelul nr. 4. Fragment de conversa ie $n r .4$

\begin{tabular}{|c|c|}
\hline Interac iuni verbale & $\begin{array}{l}\text { Structură } \\
\text { participare }\end{array}$ \\
\hline 1.Î: Hai să îl şi descoperim. & $\hat{\mathrm{I}}$ \\
\hline $\begin{array}{l}\text { 2.Î Ahh... Dragoş, ai zis că ştii să scrii pe-pe-ne. Hai! (în jur, mai mul i } \\
\text { elevi ridică mâna şi spun că vor să răspundă) }\end{array}$ & $\hat{\mathrm{I}}$ \\
\hline 3.Î̀ : Ştiu că mul i şti i, dar scrie i-l înainte să fie pe tablă. & $\hat{\mathrm{I}}$ \\
\hline 4.E: Eu am scris! & $\mathrm{E}$ \\
\hline 5. I: Foarte bine! & $\hat{\mathrm{I}}$ \\
\hline 6.Î: Uite, Dragoş va scrie PEPENE, să vedem dacă corect. & $\hat{\mathrm{I}}$ \\
\hline $\begin{array}{l}\text { 7.Î: Mai mare, Dragoş, vreau litere mari, uite, vezi ce litere mari au făcut } \\
\text { copiii, că la tablă dacă nu sunt mari, nu se văd. Aşa! }\end{array}$ & $\hat{\mathrm{I}}$ \\
\hline 8.Î́: Peeee...uite-1 cum a apărut primul e. PEEEE. Aşa! & $\hat{\mathrm{I}}$ \\
\hline 9.E:... (inaudibil) & $\mathrm{E}$ \\
\hline 10.Î: Georgiana nu vorbi! & $\hat{\mathrm{I}}$ \\
\hline 11.Î:Peeee-Pe-E! Ia uite şi al doilea E. & $\hat{\mathrm{I}}$ \\
\hline 12. Î: $\mathrm{Ne}$ & $\hat{\mathbf{I}}$ \\
\hline 13.Î: Foarte bine, Dragoşel! & $\hat{\mathrm{I}}$ \\
\hline
\end{tabular}

Activită ile de verificare, în număr de 34, sunt activită ile în care elevii participă numi i sau ridicând mâna. Interven iile libere sunt în general taxate, mai ales dacă reprezintă răspunsuri la întrebările adresate altcuiva. Sunt activită ile în care este eviden iată cunoaşterea şcolară de tip individual. 
Uneori, scopul de verificare al activită ilor se împleteşte cu scopul exersării sau al predării. $\mathrm{Cu}$ alte cuvinte, grani a dintre cele două este, în contextele studiate, foarte neclară. Următoarele două fragmente ilustrează caracteristicile activită ilor de verificare.

De exemplu, în tabelul nr.5, putem vedea că elevilor nu le este permis rândul la vorbire fără numirea profesorului. Fragmentul face parte dintr-o activitate conversa ională în care doamna învă ătoare verifică capacitatea elevilor de a-şi reaminti o serie de detalii dintr-o povestioară pe care a citit-o în aceeaşi oră. În fragment, am reperat întrebările de reamintire. Elevii răspund atunci când sunt numi i, după ce au ridicat mâna. Interven iile libere ale elevilor sunt taxate sau ignorate. În replica 2, învă ătoarea atrage tuturor elevilor aten ia că nu se răspunde, ,aşa”, după care numeşte un elev. În rândurile 7-8, putem observa aceeaşi situa ie.

Tabelul nr. 5. Fragment de conversa ie nr. 5

\begin{tabular}{|c|c|}
\hline Interac iuni verbale & $\begin{array}{l}\text { Structură } \\
\text { participare }\end{array}$ \\
\hline $\begin{array}{l}\text { 1.Î: Ia să vedem, cine este Eli? (se aud elevii vocalizând, ridicând mana } \\
\text { cu dorin a de a răspunde). }\end{array}$ & $\hat{\mathrm{I}}$ \\
\hline 2.Î:Nu aşa!! (le spune tuturor elevilor) Bogdan. & $\hat{\mathrm{I}}$ \\
\hline 3.B:Elefantul. & $\mathrm{E}$ \\
\hline 4.Î: Eli... hai sa răspundem şi noi cu mai multe cuvinte. Eli... & $\hat{\mathrm{I}}$ \\
\hline 5.D:Eli este elefantul. & $\mathrm{E}$ \\
\hline 6.E: Şi are trompa! & $\mathrm{E}$ \\
\hline $\begin{array}{l}\text { 7.I:Un elefant, dar ce fel de elefant? Că nu e un elefant obişnuit care } \\
\text { aleargă prin junglă, prin savană. Zi, ahhh..Carmen. Ce fel de elefant este } \\
\text { acesta? }\end{array}$ & $\hat{\mathrm{I}}$ \\
\hline 8.E: Talentat. & $\mathrm{E}$ \\
\hline 9.I: Te cheamă Carmen, mai nou?! & $\mathrm{I}$ \\
\hline 10.C: Eli este un elefant talentat. & $\mathrm{E}$ \\
\hline
\end{tabular}

Am spus anterior că, uneori, activită ile de verificare se împletesc cu cele de exersare. În tabelul nr. 6 putem observa o astfel de situa ie. Repetarea lunilor de toamnă vine după precizarea învă ătoarei, realizată în rândul 1: le solicitase să repete lunile toamnei, iar acum vrea să vadă ,cine poate să spună”, urmând a numi un elev. Scopul este clar de verificare, elevii nu răspund fără a fi numi i, însă modalitatea de desfăşurare este una specifică exersării, pentru că oferă sprijin (rândurile 8-18). În final, propune elevilor să repete în cor. 
Tabelul nr. 6. Fragment de conversa ie nr. 6

\begin{tabular}{|c|c|}
\hline Interac iuni verbale & $\begin{array}{l}\text { Structură } \\
\text { participare }\end{array}$ \\
\hline $\begin{array}{l}\text { 1.Î: Mai e ceva scris în col ul de sus şi eu v-am rugat zilele trecute să } \\
\text { repeta i acasă lunile de toamnă. Cine poate să îmi spună care sunt } \\
\text { lunile de toamnă? (elevii se aud vorbind în fundal) }\end{array}$ & $\hat{\mathrm{I}}$ \\
\hline 2. İ: Vlad! & $\hat{\mathrm{I}}$ \\
\hline 3.V: Decem...Septembrieee, octombrie, noiembrie. & $\mathrm{E}$ \\
\hline 4.1̂:Foarte bine! Cine poate să ne spună încă o data? Daniel! & $\hat{\mathrm{I}}$ \\
\hline 5.D: Septembrie, octombrie, noiemmmbrie. & $\mathrm{E}$ \\
\hline 6.1̂: Bine, Daniel. Altcineva! Mihaela. & $\hat{\mathrm{I}}$ \\
\hline 7.M:.... & $\mathrm{E}$ \\
\hline 8.Î: Sep.. & $\hat{\mathrm{I}}$ \\
\hline 9.M: Septembrie, octoooombrie, noieeemmmbrie. & $\mathrm{E}$ \\
\hline 10.Î: Foarte bine. Altcineva. Mihai. & $\hat{\mathrm{I}}$ \\
\hline 11.M: Setem.. & $\mathrm{E}$ \\
\hline 12.Î: Septembrie! Cu P, Septembrie. & $\hat{\mathrm{I}}$ \\
\hline 13.Mihai: .... & $\mathrm{E}$ \\
\hline 14.Î: Oc... & $\hat{\mathrm{I}}$ \\
\hline 15.M: Octombrie & $\mathrm{E}$ \\
\hline 16.Î: No.. & $\hat{\mathrm{I}}$ \\
\hline 17.M: noembrie & $\mathrm{E}$ \\
\hline $\begin{array}{l}\text { 18.î: Noiembrie, da? } \mathrm{Nu} \text {,noembrie”. Noiembrie. Încă o dată, le } \\
\text { spunem cu to ii în cor. }\end{array}$ & $\hat{\mathrm{I}}$ \\
\hline
\end{tabular}

\subsection{Profesorul în interac iune cu întreaga clasă}

Procedurile analitice mi-au permis să descriu structurile de participare prezente în cele două contexte, structuri care diferă de la o activitate la alta, uneori chiar în cadrul aceleiaşi activită i. În cadrul fiecărei activită i, am codat interven iile participan ilor cu coduri ce descriau cine cu cine interac ionează. Ca o caracteristică generală, discursul clasei este dominat de profesorul în interac iune cu întreaga clasă sau cu un singur elev. În tabelul nr. 7 se poate observa numărul interac iunilor, după scopul activită ii. 
Tabelul nr. 7. Tipul de interac iuni după scopul activită ii

\begin{tabular}{|l|l|l|l|l|l|}
\hline & Elevi-Prof. & Elev-elevi & Elev-Prof. & Prof.-Elev & Prof.-Elevi \\
\hline Predare & 49 & 55 & 27 & 100 & 306 \\
\hline $\begin{array}{l}\text { Exersare/ } \\
\text { Consolidare }\end{array}$ & 29 & 63 & 230 & 314 & 280 \\
\hline Verificare & 43 & 295 & 150 & 606 & 400 \\
\hline Tranzi ie & 20 & 22 & 60 & 71 & 174 \\
\hline Total & 141 & 435 & 467 & 1091 & 1160 \\
\hline
\end{tabular}

Punând laolaltă datele prezentate anterior, au rezultat mai multe tipuri de structuri de participare, care func ionează în contextele de instruire investigate: 1. Învă ătoarea se adresează tuturor elevilor, iar aceştia pot face interven ii libere, fără să ridice mâna sau să aştepte să fie numi i. În aceste situa ii interven iile elevilor sunt fie individuale, fie colective (activită i de tranzi ie şi predare).

2. Învă ătoarea se adresează tuturor elevilor sau unui singur elev, iar aceştia pot face interven ii doar dacă ridică mâna şi/sau sunt numi i. Nu sunt permise interven iile libere (activită i de exersare).

3. Învă ătoarea se adresează unui singur elev. Elevii pot face interven ii libere pentru a solicita ajutorul (în activită i de exersare individuală, pe caiet).

4. Învă ătoarea se adresează tuturor elevilor, iar elevii nu pot face interven ii (lectură).

5. Învă ătoarea se adresează elevilor sau unui singur elev, iar aceştia participă dacă sunt numi i sau dacă ridică mâna şi sunt numi i (verificare).

6. Elevii se adresează învă ătoarei, individual sau în cor, fără să fie numi i sau fără să ridice mâna (predare).

7. Elevii se adresează învă ătoarei, individual, ridicând mâna şi/sau aşteptând să fie numi i (exersare şi verificare).

8. Elevii ascultă ceea ce spune/citeşte învă ătoarea, fără a face interven ii (lectură).

Să observăm, în primul rând, că interac iunile dintre elevi lipsesc. Acestea apar doar ca interac iuni verbale ,,subterane”, neratificate în discursul şcolar al clasei (Goffman, 1974) şi sunt taxate de profesor. 
În al doilea rând, preponderen a interac iunilor dominate de profesor în discursul clasei poate fi interpretată din perspectiva autorită ii epistemice a acestuia. Cadrul didactic validează sau invalidează interven iile elevilor. Putem observa în fragmentele de interac iuni verbale, prezentate anterior, că structura este de obicei Î-E-Î-E-Î, adică o succesiune extrem de predictibilă a interven iilor celor doi actori, învă ătoare - elev. Există câteva excep ii în cadrul activită ilor de predare (tab. nr. 1, rânduri 8-9), care arată structura mai relaxată a participării. $\mathrm{O}$ excep ie putem observa şi în tabelul nr. 5, rândurile 5-6, însă a doua interven ie a elevului, dată fiind structura de participare a activită ii de verificare, nu este ratificată, este ignorată. Activită ile sunt, prin urmare, organizate în jurul interven iilor realizate de profesor, adresate fie către un singur elev, fie către întreaga clasă. Există şi alte tipuri de interac iuni a căror utilizare pare a fi modelată de scopul activită ii. De exemplu, în cadrul activită ilor de exersare, individuale, elevii se adresează liber, solicitând ajutor învă ătoarei. Pe de altă parte, într-o activitate de lectură, elevii nu pot interveni până când cadrul didactic nu le permite interven ii.

\subsection{Contribu ia elevilor la discursul clasei}

În urma analizei, un alt rezultat ob inut se referă la măsura şi modul în care elevii contribuie la discursul clasei. Analizând structurile de participare de la clasă acestea variază de la un tip de activitate la altul, ceea ce ar putea însemna că interac iunile verbale din clasă nu sunt coordonate doar pe baza unor reguli de comunicare, ci şi pe baza scopurilor activită ilor. Participarea elevilor la activită ile de la clasă se desfăşoară după o serie de reguli, să le spunem discursive, prin care este înlesnită, mai degrabă, comunicarea cunoaşterii de tip şcolar, prescrisă prin curriculum. Elevii sunt încuraja i să participe şi să aplice anumite reguli, nu doar pentru a învă a să comunice unii $\mathrm{cu}$ al ii, dar mai ales pentru a se exercita control asupra a ceea ce pot spune şi ceea ce nu pot spune, prin raportare la o cunoaştere de tip şcolar.

Există situa ii în care elevii, deşi nu încalcă nicio regulă de comunicare în situa ia respectivă - interven iile lor sunt adec vate atât la scopul activită ii, cât şi la structura de participare -, sunt taxa i pentru interven ia lor. Acest lucru poate fi observat în tabelul nr. 2, în care elevul întreabă despre ora de sport. Nouă ne place sportul, spune el, iar cadrul didactic răspunde: ,,dar nu mă interesează, acum ne vedem de treabă şi după, vă duce i şi la ora de 
sport!". Discursul educa ional al elevilor intră în opozi ie cu discursul şcolar, pe care cadrul didactic îl favorizează. Elevul de clasa pregătitoare poate că a deprins regulile de interac iune - când poate întreba despre lucruri din afara orei (în timpul activită ilor tranzitive) - dar nu a deprins încă regulile de comunicare ale diferitelor discursuri: discursul şcolar vs. discursul, mai larg, de tip educa ional, care poate include şi o discu ie despre ora de sport. Această situa ie poate fi comparată cu fragmentul din tabelul nr. 3. Învă ătoarea este întreruptă de un elev care aduce în discu ie o nemul umire şi o preocupare congruentă cu discursul şcolar - de ce nu îl înva ă pe „L” şi când înva ă o nouă literă. Pare că interven iile elevilor sunt aici percepute ca fiind productive, deşi ele încalcă regulile de comunicare, pentru că o întrerup pe doamna învă ătoare. Putem spune că spa iul discursiv al clasei operează cu o grani ă foarte clară între cele două tipuri de cunoaştere: cunoaşterea şcolară şi cunoaşterea personală a elevilor care poate fi pusă sub numele de cunoaştere educa ională, pentru că apare în spa iul clasei. Organizarea activită ilor cadrează, modelează, adesea, ceea ce elevii pot spune sau nu pot spune.

\section{Concluzii}

Prin acest studiu am propus o abordare pedagogică a cunoaşterii, adică orientată către ceea ce se întâmplă în clasă, din punctul de vedere al predării şi interac iunilor (Păun, 2017), ca procese de construc ie a cunoaşterii educa ionale. Prin acest concept desemnez versiuni de cunoaştere care apar în spa iul şcolar, incluzând ceea ce profesorul transmite - cunoaşterea şcolară, dar şi ceea ce elevii exprimă sub forma cunoaşterii cotidiene şi personale, exprimată prin nara iunile şi interven iile lor spontane.

În spa iul discursiv al celor două clase analizate predomină activită ile al căror scop este exersarea şi verificarea cunoştin elor, urmate de activită ile de tranzi ie şi de cele de predare. Pe baza datelor, apreciez că gestionarea participării elevilor la aceste activită i nu are atât legătură cu reguli de comunicare, ci mai mult cu transmiterea şi construc ia cunoaşterii de tip şcolar, în detrimentul celei cotidiene, a elevilor. Activită ile de predare-învă are func ionează ca resurse de cadrare a discursurilor de la clasă, modelând ceea ce elevii pot spune, cum pot spune şi când pot spune. 
În urma analizei datelor am identificat şi definit opt tipuri de structuri de participare, definite ca reguli mutual împărtăşite, care reglementează interven iile participan ilor la un context discursiv. Fiecare categorie de activitate tinde să fie caracterizată de anumite structuri de participare, implicit anumite limbaje şi modalită i prin care elevii pot contribui la discursul clasei. Cum activită ile predominante sunt cele de exersare şi verificare, structurile de participare cele mai frecvente pun în centrul spa iului interac ional al clasei interven iile realizate şi controlate de învă ătoare: se adresează unui singur elev sau întregii clase, numeşte elevii. Participarea elevilor este, astfel, limitată. În plus, preponderen a interac iunilor dominate de profesor în discursul clasei poate fi interpretată, totodată, din perspectiva autorită ii epistemice a acestuia.

În cele două contexte, resursele de cadrare eviden iate - scopul activită ilor şi structurile de participare - favorizează discursul cunoaşterii şcolare sub forma unui ,un produs cognitiv finit, prefabricat, transmis de profesor, iar nu un proces, în care elevul are de jucat un rol activ" (Iosifescu, 2012, p. 95). Acest rezultat poate fi valorificat prin studii ulterioare, care să arate cum şi dacă schimbările la nivelul activită ilor - creşterea numărului de activită i de predare - dar mai ales modificarea structurilor de participare - adoptarea unor structuri specifice activită ilor de predare sau de tranzi ie, în cadrul celor de exersare şi chiar a celor de verificare, schimbă dinamica şi participarea elevilor la clasă.

Abordarea propusă prin studiul de fa ă ne invită să reflectăm, totodată, la rela ia dintre practica şcolară şi conceptele care apar în programele şcolare pentru limbă şi comunicare din învă ământul primar, precum ,interesele elevilor" sau ,universul elevilor", concepte care fac trimitere către acceptarea în spa iul şcolar a unei cunoaşteri cotidiene, personale, venite dinspre elev. Dacă luăm în considerare datele analizate, constatăm că aceste idei îşi fac cu greu loc în spa iul discursiv al clasei, dominat de activită i cu scop de verificare şi exersare, dar şi de structuri de participare în care elevii nu îşi pot exprima interesele sau modurile lor de a în elege lumea prin nara iuni şi limbaje proprii, deşi sunt într-un spa iu de învă are dedicat comunicării.

O altă concluzie a acestui studiu este că, analizând caracteristicile contextelor discursive ale clasei, putem creiona o anumită reprezentare despre ceea ce 
intră sub umbrela cunoaşterii şcolare şi ceea ce este definit ca fiind în afara acesteia. Consecin a este aceea că, aşa cum a arătat şi Philips (1972), discursul de la clasă, prin cadrele de participare, pot limita vocea elevilor. Modul în care definim cunoaşterea şcolară include sau exclude şi validează sau invalidează anumite spa ii sociale. Deşi în programele şcolare no iuni precum ,universul elevului”, ,,interesele elevilor” sunt frecvent invocate, în discursul de la clasă, aceste reprezentări încă mai luptă să îşi facă loc.

\section{Mul umiri}

Acest studiu face parte din proiectul de cercetare doctorală a autoarei şi a fost sus inut printr-o bursă de studiu acordată de Universitatea din Bucureşti. Studiul va fi publicat inclusiv în teza de doctorat.

\section{Referin e}

- Bercu, N., Nasta, D.I., \& Teşileanu, A. (2012). Mecanisme şi practici de aplicare şi de dezvoltare a curriculumului la nivel de şcoală şi de clasă. Sinteza raportului de cercetare. http://www.ise.ro/wpcontent/uploads/2012/08/ Sinteza_Raport_-2012_Curriculum.pdf

- Bereiter, C. (2001). Education and mind in the Knowledge Age. Lawrence Erlbaum Associates Publishers.

- Bloome, D., Carter, S.P., Christian, B.M., \& Otto, S. (2004). Discourse analysis and the study of classroom language and literacy events: A microethnographic perspective. Routledge.

- Bruner, J. (1996). The culture of education. Harvard University Press.

- Cazden, C.B. (2001). Classroom discourse: The language of teaching and learning. Heinemann.

- Cunningham, J. W., \& Fitzgerald, J. (1996). Epistemology and reading. Reading research quarterly, 31(1), 36-60. https://doi.org/10.1598/RRQ.31.1.3

- Edwards, D., \& Mercer, N. (1987). Common knowledge: The development of understanding in the classroom. Methuen/Routledge.

- Garton, S. (2012). Speaking out of turn? Taking the initiative in teacher-fronted classroom interaction. Classroom Discourse, 3(1), 29-45. https://doi.org/10.1080/19463014.2012.666022

- Goffman, I. (1974). Frame analysis: An essay on the organization of experience. Harper. 
- Goldman, A.I. (1999). Knowledge in a Social World. Oxford University Press.

- Heller, V. (2017). Managing knowledge claims in classroom discourse: the public construction of a homogeneous epistemic status. Classroom Discourse, 8(2), 156-174. https://doi.org/10.1080/19463014.2017.1328699

- Houen, S., Danby, S., Farrell, A., \& Thorpe, K. (2019). Adopting an unknowing stance in teacher-child interactions through 'I wonder...' formulations. Classroom Discourse, 10(2), 151-167.

https://doi.org/10.1080/19463014.2018.1518251

- Iosifescu, Ş. (coord.) (2012). Analiza mediului şcolar în raport cu implementarea reformei curriculare. Editura Didactică şi Pedagogică.

- ISE (2019). Repere pentru proiectarea, Actualizarea şi Evaluarea Curriculumului Na ional. Document de politici Educa ionale. https:// www.edu.ro/consultare-public\%C4\%83-documentul-de-politici-curriculare$\%$ E2\%80\%9Erepere-pentru-proiectarea-\%C8\%99i-actualizarea

- Markee, N. (2015). The Handbook of Classroom Discourse and Interaction. Wiley Blackwell.

- Mihăilescu, A. (2016). L'expérience de l'enseignement en collaboration. une étude exploratoire portant sur le format de l'interaction enseignant - architecte en Roumanie. În I. Boldea (Coord.), Globalization and National Identity. Studies on the Strategies of Intercultural Dialogue. Arhipelag XXI Press. https:// old.upm.ro/gidni3/GIDNI-03/Pse/Pse\%2003\%2051.pdf

- Moje, E.M. (2008). Everyday funds of knowledge and school discourses. În A.M. de Mejia \& M. Martin-Jones (Eds.), Encyclopedia of language and education: Vol. 3. Discourse and education (pp. 341-355). Springer.

- Moore, R., \& Young, M. (2001). Knowledge and the Curriculum in the Sociology of Education: Towards a reconceptualisation. British Journal of Sociology of Education, 22(4), 445-461. https://doi.org/10.1080/01425690120094421

- Păun, E. (2017). Pedagogie. Provocări şi dileme privind şcoala şi profesia didactică. Polirom.

- Philips, U.S. (1993). The Invisible Culture: Communication in Classroom and Community on the Warm Spring Reservation. Waveland Press. Kindle Edition.

- Rymes, B. (2016). Classroom discourse analysis: A tool for critical reflection. Routledge.

- Saldaña, J. (2009). The coding manual for qualitative researchers. SAGE Publications.

- Vlăsceanu, L. (coord.) (2002). Şcoala la răscruce. Schimbare şi continuitate în curriculumul învă ământului obligatoriu. Polirom. 


\begin{tabular}{|c|c|}
\hline $\begin{array}{l}\text { The online version of this article can be found at: } \\
\text { http://revped.ise.ro/category/2020-en/ } \\
\qquad \text { (cc) EY-NC-sA }\end{array}$ & $\begin{array}{l}\text { Versiunea online a acestui articol poate fi găsită la: } \\
\text { http://revped.ise.ro/category/2020-ro/ } \\
\text { (cc) BV-No-sA }\end{array}$ \\
\hline $\begin{array}{c}\text { This work is licensed under the Creative Commons } \\
\text { Attribution-NonCommercial-ShareAlike } 4.0 \\
\text { International License. }\end{array}$ & $\begin{array}{c}\text { Această lucrare este licen iată sub Creative } \\
\text { Commons Attribution-NonCommercial-ShareAlike } \\
\text { 4.0 International License. }\end{array}$ \\
\hline $\begin{array}{c}\text { To view a copy of this license, visit } \\
\text { http://creativecommons.org/licenses/by-nc-sa/4.0/ } \\
\text { or send a letter to Creative Commons, } \\
\text { PO Box 1866, Mountain View, CA 94042, USA. }\end{array}$ & $\begin{array}{l}\text { Pentru a vedea o copie a acestei licen e, vizita i } \\
\text { http://creativecommons.org/licenses/by-nc-sa/4.0/ } \\
\text { sau trimite i o scrisoare către Creative Commons, } \\
\text { PO Box 1866, Mountain View, CA 94042, SUA. }\end{array}$ \\
\hline
\end{tabular}

